\title{
An endoscopic multimodal approach in a patient with blue rubber bleb nevus syndrome and acute bleeding
}

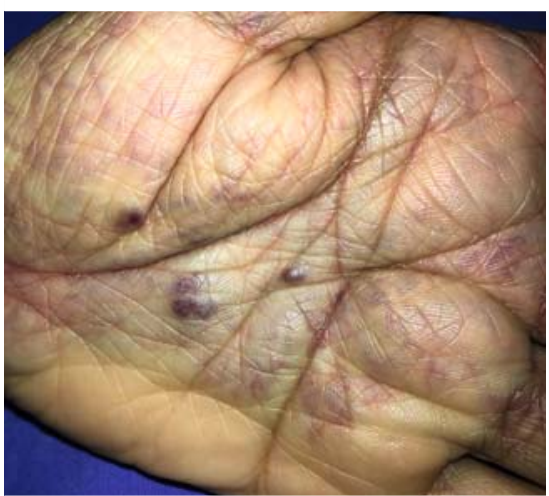

- Fig. 1 Violaceous soft papules in the hand, lesions that are characteristic of blue rubber bleb nevus syndrome.

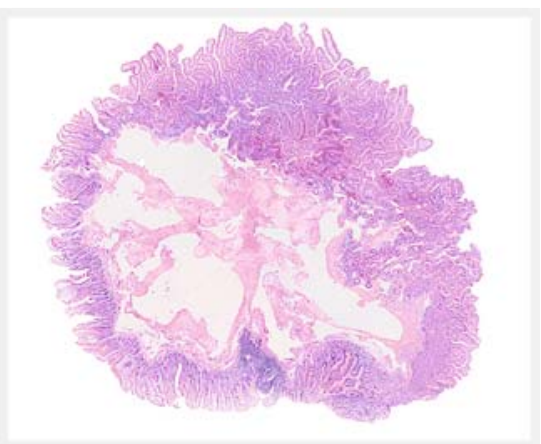

Fig. 2 Histopathology of the resected lesion showing tortuous, ectatic vessels with red blood cells, lined by a single layer of endothelium, compatible with a hemangioma.

Blue rubber bleb nevus syndrome is a rare disease characterized by multiple venous malformations found in various organs, among which the gastrointestinal (GI) tract stands out [1]. Patients frequently suffer Gl bleeding and iron deficiency anemia. Many endoscopic therapeutic options have been implemented for treatment of this syndrome, such as endoscopic sclerotherapy $[2,3]$, endoscopic band ligation, detachable snare [4], and even endoscopic submucosal dissection [5].

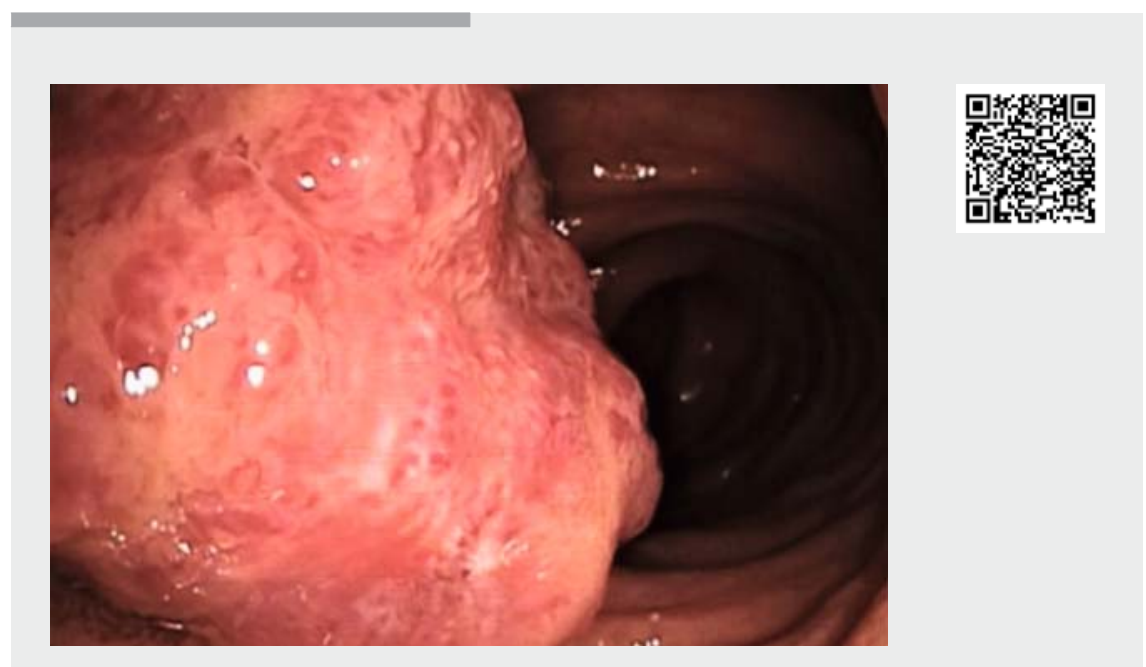

$\square$ Video 1 Venous malformation in the jejunum. a Endoscopic capsule. $b$ Single-session multimodal approach in blue rubber bleb nevus syndrome. c Follow-up enteroscopy.

Herein we present the case of a 44-yearold man with a diagnosis of blue rubber bleb nevus syndrome (\$ Fig.1) who arrived at the emergency department after 2 days with melena. Laboratory findings on admission reported microcytic anemia (hemoglobin $8.9 \mathrm{~g} / \mathrm{dl}$, mean corpuscular volume $77 \mathrm{fL}$ ) and mild thrombocytopenia $(138 \mathrm{~K} / \mathrm{uL})$. Upper endoscopy disclosed purplish lesions on the hypopharynx, esophagus, stomach, and duodenum without signs of active or recent bleeding. A colonoscopy showed hemangiomas in the left colon and the rectum without signs of active or recent bleeding. An endoscopic capsule revealed purplish blebs larger than $10 \mathrm{~mm}$ at the proximal jejunum with active bleeding ( $\vee$ Video 1). Finally, an anterograde enteroscopy was performed showing 8 hemangiomas in the jejunum. Cyanoacrylate was applied in a large lesion $(>2 \mathrm{~cm})$, a snare resection was performed in two lesions, and a detachable snare was inserted in another ( $>$ Fig. 2, $>$ Video $\mathbf{1}$ ). The patient remained without clinical or laboratory signs of gastrointestinal bleeding, therefore he was discharged without further complications. A followup enteroscopy was performed 14 weeks after his discharge, which showed adequate scaring. Signs of neovascularization were observed in the sites of snare resection and detachable snare insertion, with the application of argon plasma in the site of snare resection being necessary ( $>$ Video 1 ).

In conclusion, there is no technique of choice for endoscopic management of the blue rubber bleb nevus syndrome; however an endoscopic multimodal approach is effective in the treatment of acute bleeding in these patients.

Endoscopy_UCTN_Code_TTT_1AP_2AD

Competing interests

The authors declare that they have no conflict of interest. 
Alejandro Campos-Murguía', Luis Eduardo Zamora-Nava ${ }^{2}$

1 Department of Gastroenterology, Instituto Nacional de Ciencias Médicas y Nutrición Salvador Zubirán, Mexico City, Mexico

2 Department of Gastrointestinal Endoscopy, Instituto Nacional de Ciencias Médicas y Nutrición Salvador Zubirán, Mexico City, Mexico

\section{Corresponding author}

Dr. Luis Eduardo Zamora-Nava, MD Department of Gastrointestinal Endoscopy, Instituto Nacional de Ciencias Médicas y Nutrición Salvador Zubirán, Vasco de Quiroga 15, Belisario Domínguez Secc 16, Tlalpan, 14080 Mexico City, Mexico luiseduardozn@gmail.com
[1] Jin XL, Wang ZH, Xiao XB et al. Blue rubber bleb nevus syndrome: a case report and literature review. World J Gastroenterol 2014; 20: 17254-17259

[2] Dwivedi M, Misra SP. Blue rubber bleb nevus syndrome causing upper $\mathrm{Gl}$ hemorrhage: a novel management approach and review. Gastrointest Endosc 2002; 55: 943-946

[3] Mavrogenis G, Coumaros D, Tzilves D et al. Cyanoacrylate glue in the management of blue rubber bleb nevus syndrome. Endoscopy 2011; 43: 291-292

[4] Jin J, Pan J, Zhu L. Therapy for hemangiomas of blue rubber bleb nevus syndrome in the small intestine with single balloon endoscopy. Dig Endosc 2015; 27: 780

[5] Chen W, Chen H, Shan G et al. Blue rubber bleb nevus syndrome: our experience and new endoscopic management. Medicine (Baltimore) 2017; 96: 7792
Bibliography

Endoscopy 2021; 53: E338-E339

DOI 10.1055/a-1287-8987

ISSN 0013-726X

published online 11.11 .2020

(c) 2020. Thieme. All rights reserved.

Georg Thieme Verlag KG, Rüdigerstraße 14,

70469 Stuttgart, Germany

\section{ENDOSCOPY E-VIDEOS}

https:|/eref.thieme.de/e-videos

回局 Endoscopy E-Videos is a free 留 自: on interesting cases and new techniques in gastroenterological endoscopy. All papers include a high quality video and all contributions are freely accessible online.

This section has its own submission website at

https://mc.manuscriptcentral.com/e-videos 